\title{
Pertunjukan Rejung dalam Tradisi Begareh Malam Bujang Gadis pada Masyarakat Pagar Alam
}

\author{
Oleh: \\ Berliansyah Rumodhon \\ Pascasarjana Institut Seni Indonesia Padangpanjang \\ Email: berliansyah.rmd@gmail.com Telp.082180005454
}

\begin{abstract}
Abstract. This paper has an aim to reveal Rejung as a traditional show of begareh in malam bujang gadis, as a part of wedding ceremony of Besemah people, Pagar Alam, South Sumatera. Rejung is a traditional music show in a form of pantun, sung and followed with guitar, as an entertainment media in wedding tradition in malam bujang gadis. In malam bujang gadis, there is a tradition called begareh. The youth gather to help the works in wedding ceremony. Nowadays, Rejung has been a place to find mate. Begareh has a uniqueness, It's a freedom to confess their feeling with pantun to seduce their mate. Rejung is used as a communication media, that has verbal and musical communication. The method used in this research is qualitative. The data collecting is done through observation and interview. The result of this research shows that Rejung has become a communication media and interaction among the youth to find their mate in wedding tradition of Besemah people, in Pagar Alam.
\end{abstract}

Key words: Rejung, begareh, malam bujang gadis, Basemah, Pagar Alam

\begin{abstract}
Abstrak. Tulisan ini bertujuan untuk mengungkap pertunjukan Rejung pada tradisi begareh dalam malam bujang gadis pada tradisi perkawinan masyarakat Besemah, Pagar Alam, Sumatera Selatan. Rejung adalah pertunjukan musik tradisi berupa pantun yang ditembangkan dan diiringi dengan gitar sebagai media hiburan dalam tradisi perkawinan pada malam bujang gadis. Pada malam bujang gadis terdapat tradisi begareh, yaitu berkumpulnya muda-mudi untuk membantu pekerjaan dalam upacara perkawinan. Pada saat ini Rejung dijadikan sebagai media mencari pasangan. Tradisi begareh memiliki keunikan, yaitu kebebasan mengungkapkan perasaan melalui pantun untuk merayu pasangan. Rejung digunakan sebagai media komunikasi yang memiliki makna komunikasi verbal dan komunikasi musikal. Metode yang digunakan dalam penelitian ini adalah metode kualitatif. Pengumpulan data dilakukan melalui observasi, pengamatan, dan wawancara. Hasil penelitian menunjukkan bahwa Rejung menjadi media komunkasi dan interaksi antara pemuda dan pemudi dalam mencari pasangan dalam tradisi perkawinan masyarakat Besemah di Pagar Alam.
\end{abstract}

Kata kunci: Rejung, begareh, Malam bujang gadis, Besemah, Pagar Alam 


\section{PENDAHULUAN}

Salah satu kesenian tradisional yang ada di Pagar Alam adalah sastra tutur yang masih bertahan hingga sekarang. Sastra tutur memiliki beberapa jenis dan genre, seperti tangis ayat, tadud, guritan dan Rejung. Masing-masing memiliki ragam karakter, fungsi, dan konteks yang berbeda-beda. Dari berbagai macam jenis sastra tutur, salah satu seni tutur yang populer di kota ini adalah Rejung. Secara harfiah Rejung dapat diartikan oleh masyarakat Besemah, yaitu pantun yang dinyayikan atau di tembangkan. Rejung adalah tembang yang berisikan pantun. Orang yang menyajikan Rejung disebut penembang Rejung. Rejung biasanya disajikan oleh satu atau dua orang pemain, ditampilkan sebagai hiburan pada acara perkawinan masyarakat Besemah di Pagar Alam. (Arman, wawancara 3 Januari 2017, Tegur Wangi Pagar Alam ). Suku Besemah memiliki ragam adat istiadat salah satunya dalam acara perkawinan. Aturan yang ada dalam adat perkawinan Besemah merupakan aturan adat yang tidak boleh ditambah atau dikurangi pada saat melakukan sebuah acara perkawinan. Adapun beberapa susunan acara perkawinan adat pada suku Besemah yang harus mengikuti peraturan adat seperti; pembentukan panitia, saghian negak bangsal, saghiani bemasak, mipes bumbu, malam bujang gadis, sangian jadi, penutupan panitia, dan mbongkar tarup ( Satarudin, wawancara 18 Oktober 2016, Pagar Alam).

Hal yang menarik pada susunan acara pada adat perkawinan masyarakat Besemah adalah malam bujang gadis. Pada malam bujang gadis adalah tempat berkumpul para muda-mudi untuk membantu tuan rumah yang melakukan pesta perkawinan untuk membuat dekorasi atau hiasan untuk kebutuhan pada pesta perkawinan. Malam bujang gadis merupakan tradisi yang sangat unik yaitu terdapat satu tradisi yang disebut begareh yang dijadikan sebagai media interaksi menarik perhatian lawan jenis hingga menjadi ajang mencari jodoh dalam tradisi begareh. Dalam bahasa Besemah, begareh berarti datang menemui seseorang wanita; dari kata be yang berarti ada dan kata gareh yang berarti temu sehingga dapat diartikan bertemu. Adat begareh tidak hanya ada dalam malam bujang gadis pada perkawinan. Begareh juga bisa disebutkan pada saat seorang laki-laki mendatangi seorang wanita, tetapi istilah begareh yang lebih terkenal pada suku Besemah yaitu saat malam bujang gadis pada pesta perkawinan. Tradisi begareh biasanya tidak lepas tradisi pertunjukkan Rejung di dalamnya. Begareh dan Rejung sangat berkaitan, biasanya Rejung dipakai sebagai media komunikasi oleh para mudamudi untuk mengungkapkan isi hatinya melalui pantun. Penembang dan pantunpantun yang ada pada Rejung pada tradisi begareh biasanya bersifat spontan. Menurut istilah populer pada bahasa Besemah " bekate amu injik" yang berarti "katakan kalau suka" yang membuat siapa saja yang berkeinginan mengungkapkan rasa suka pada lawan jenis boleh dilakukan dengan mengikuti aturan dan norma adat yang berlaku pada masyarakat Besemah dalam tradisi begareh.

Pertunjukan Rejung pada acara begareh di malam bujang gadis banyak terjadi interaksi dua arah dari penembang dan penonton terkadang tidak menutup 
kemungkinan ada balasan pantun dari wanita yang merasa tersindir oleh pantun yang ditembangkan. Bahkan respons yang didapatkan oleh penembang bisa menjadi respons yang mengundang gelak tawa dari penonton. Bagaimana bentuk pertunjukan tradisi Rejung pada malam bujang gadis dalam masyarakat Besemah di Kota Pagar Alam.

Penelitian yang berkaitan dengan Rejung antara lain: Feri Firmansyah (2014), Pada tesisnya yang berjudul "Sahilin Dalam Dunia Musik Batang Hari Sembilan Di Palembang (Kesenimanan Dan Gaya Musiknya)". Firmansyah mengulas biografi dan konsistensi Sahilin sebagai seniman musik Batang Hari Sembilan. Menurut Firmansyah peran seniman menjadi salah satu faktor pendukun keberadaan kesenian tersebut tetap terjaga hingga sampai sekarang. Tesis Firmansyah mengungkapkan tentang keberlangsungan seni Rejung yang tetap terjaga hingga saat ini.

Kemudian selanjutnya skripsi Arza Wahyu Firamadhan (2014), “ Musik Rejung dalam Sastra Lisan Etnis Besemah Kabupaten Pagar Alam". Membahas seni pertunjukan Rejung pada etnis Besemah di Kota Pagar Alam, mulai dari sejarah hingga perkembangan musik Rejung dalam sastra lisan etnis Besemah. Firamadhan menulis perkembangan seni Rejung pada saat ini sudah mulai hilang tergerus zaman. Berkembangnya musik modern di kehidupan masyarakat sekarang membuat semakin ditinggalkanya musik Rejung. Firamadhan juga menuliskan ada beberapa perkembangan Rejung, tidak hanya diiringi oleh gitar akan tetapi juga diiringi oleh alat musik gesek seperti biola.

Selanjutnya, Misral et al (2014) menulis buku Musik Etnnik di Sumatera Selatan, yang membahas tentang keberagaman Musik Etnik di Sumatera Selatan sebagai identitas budaya, dan musik etnik di Kota Pagar Alam. Buku ini memberikan informasi tentang berbagai ragam jenis seni pertunjukan yang ada di Kota Pagar Alam khususnya seni pertunjukan Rejung. Buku ini menjelaskan berbagai macam kesenian termasuk kesenian musik yang ada di provinsi Sumatera Selatan salah satunya adalah Rejung. Dari ketiga tulisan diatas belum ada yang membahas tentang Rejung dalam tradisi begareh pada malam bujang gadis di Kota Pagar Alam, Sumatera Selatan.

\section{METODE}

Metode yang digunakan dalam penelitian ini adalah metode kualitatif, teknik pengumpulan data seperti observasi, penelitian lapangan, wawancara, dan dokumentasi. Observasi dilakukan dengan melihat proses pertunjukan Rejung yang ada pada tradisi begareh pada malam bujang gadis yang ada di Kota Pagar Alam. Penelitian lapangan dilakukan untuk mengetahui apa saja yang terjadi pada pertunjukan Rejung, dan peneliti menemukan dua bentuk pertunjukan Rejung yang ada pada masyarakat Besemah. Wawancara dilakukan untuk mengetahui apa saja yang terjadi pada pertunjukan Rejung dalam begareh pada malam bujang gadis di Kota Pagar Alam. Wawancara dilakukan kepada beberapa orang seperti ketua Lembaga Adat Besemah, sesepuh dusun, seniman Rejung, dan pelaku atau 
masyarakat yang pernah mengikuti tradisi begareh pada malam bujang gadis di Kota Pagar Alam. Dokumentasi dilakukan dengan media kamera, dengan menggambil foto dan vidio dalam pertunjukan Rejung dalam tradisi begareh pada malam bujang gadis di Kota Pagar Alam.

\section{HASIL DAN PEMBAHASAN}

\section{Malam Bujang Gadis, Tradis Begareh, dan Nggugor Gadis}

\section{Malam Bujang Gadis}

Menurut Satarudin Tjik Olah ketua Lembaga Adat Besemah Pagar Alam, bahwa malam bujang gadis adalah malam tempat interaksi sosial bagi muda-mudi untuk menambah teman atau bahkan mencari pasangan hidup. Hal ini merupakan salah satu adat perkawinan yang tidak bisa dihilangkan. Sudah tersusun menjadi serangkaian dalam prosesi adat perkawinan suku besemah. Akan tetapi secara fungsinya adalah membantu pihak keluarga yang sedang mengadakan resepsi perkawinan dalam hal menghias dan memperindah dekorasi untuk kepentingan perkawinan tersebut. (wawancara, 13 Februari 2017).

Oleh Satarudin Tjik Olah menjelaskan lebih lanjut bawha proses tersebut merupakan proses sosial yang terjadi pada masyarakat Besemah. Hal tersebut tidak mungkin dapat dihilangkan, karena tidak ada dampak negatif pada adat tersebut. Adat istiadat Besemah memiliki batasan yang berkaitan dengan berbagai aspek seperti norma agama dan norma adat. Budaya Besemah sebelum mendapat pengaruh globalisasi, sangatlah berbanding terbalik. Pada budaya Besemah kuno terdapat "Undang-Undang Simbur Cahaya" yang mengatur cara-cara dalam bergaul.

Dalam Undang-Undang Simbur Cahaya terdapat banyak sekali pasal-pasal yang membicarakan aturan adat bagi masyarakat Besemah. Bab I Undang-Undang Simbur Cahaya, pasal 106 yang berisi "Jika laki-laki memegang gadis atau janda atau istri orang atau disebut nating gawe, dihukum denda Satu Juta Rupiah sedangkan menurut pasal 19 membayar tekap malu (menutup malu) pada perempuan setinggi-tingginya Lima Ratus Ribu Rupiah. (Himpunan Adat Istiadat Besemah, tt: 54). Kemudian dilanjutkan dengan pasal-pasal lainya, Masih pada Bab I Undang-undang Simbur Cahaya, misalnya pasal 110 yang berisi "Jika lakilaki memegang istri orang dihukum denda setinggi-tingginya Tiga Juta Rupiah, sedangkan menurut pasal 23 dan uang denda tersebut Satu Juta Lima Ratus Ribu Rupiah dibayarkan kepada perempuan atau laki-lakinya". (Himpunan Adat Istiadat Besemah, tt:155). Setelah era globalisasi ini pelanggaran pada undangundang diatas tidak lagi diberlakukan hukuman membayar uang denda. Artinya, masyarakat Besemah sudah meninggalkan undang-undang yang dibuat oleh para leluhurnya yang berkaitan dengan pasal-pasal pelanggaran memegang gadis, janda, atau istri orang. 
Berkaitan dengan adat malam bujang gadis seperti yang dinyatakan oleh Satarudin Tjik Olah diatas dan aturan adat dalam setiap perkawinan masyarakat Besemah, tampak bawha malam bujang gadis menjadi tradisi yang harus dilakukan dalam setiap adat perkawinan masyarakat Besemah di Pagar Alam. Dalam adat malam bujang gadis terdapat satu tradisi yang dijaga oleh masyarakat Besemah sebagai bentuk kesopanan dari masyarakat. Pada tradisi begareh, ada sebuah tradisi pembukaan atau perkenalan yang dilakukan oleh pemuda sebagai bentuk rasa hormat kepada tuan rumah pada tradisi begareh.

\section{Nggugor Gadis}

Dalam bahasa Besemah ngugor berarti mengetuk dan gadis adalah wanita remaja yang belum menikah. Jadi nggugor gadis berarti menyapa gadis dalam hal ini yang berarti meminta izin orang tua si gadis. Pada adat nggugor gadis ini biasanya dilakuakan ketika para laki-laki atau bujang yang baru tiba di rumah atau tempat terjadinya acara Malam bujang gadis. Menurut Arman Idris, nggugor gadis adalah sebuah tradisi adat istiadat Besemah untuk memperkenalkan diri dan permohonan agar diperbolehkan masuk ke dalam acara malam bujang gadis. Hal ini sebagai bentuk dari rasa hormat para laki-laki atau bujang yang datang untuk meminta izin kepada tuan rumah yang melakukan resepsi perkawinan, agar diperbolehkan masuk kedalam ruangan atau tempat terjadinya Malam bujang gadis.

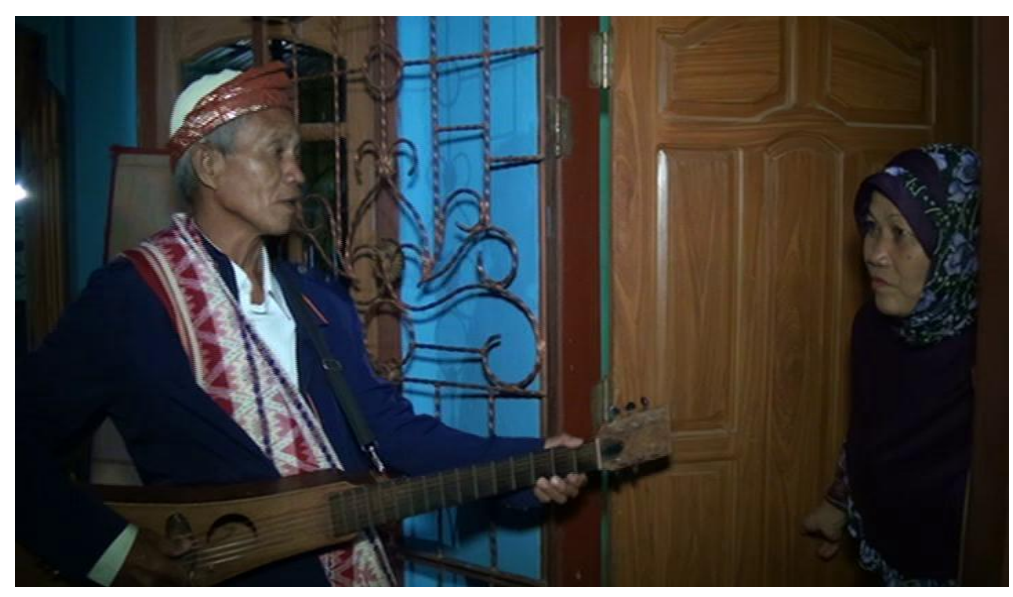

Foto 2: Tradisi nggugor gadis

\section{Begareh}

Dalam adat malam bujang gadis terdapat satu tradisi yang mendukung terjadinya interaksi sosial seperti yang diungkapkan oleh Satarudi Cjik Olah yakni tradisi begareh. Sebagaimana dijelaskan seblumnya, bahwa begareh dalam bahasa Besemah berarti datang menemui seseorang wanita. Akan tetapi dalam adat malam bujang gadis bergareh berarti datang dan bertemunya para muda-mudi untuk membantu tuan rumah dalam mendekorasi dan membuat hiasan untuk perkawinan, dan yang lebih penting dari itu adalah pertunjukan Rejung sebagai pokok dari tradisi begareh. 
Pada mulanya menurut Satarudin Cjik Olah, begareh tidak disebutkan seperti itu, hanya disebut dengan garehan yang berarti pertemuan, sebutan begareh tersebut populer pada tahun 1990an, sehingga terjadi perubahan makna. Begareh selalu terkait dengan adat malam bujang gadis pada upacara perkawinan, sedangkan garehan adalah tradisi berkumpulnya muda-mudi pada sebuah acara, tidak hanya dalam acara perkawinan saja, tetepi juga dalam acara-acara adat yang ada pada masyarakat Besemah. Kata garehan dapat juga digunakan pada saat laki-laki untuk menemui seorang gadis yang menjadi pasanganya. Pada masanya garehan identik dengan Rejung.

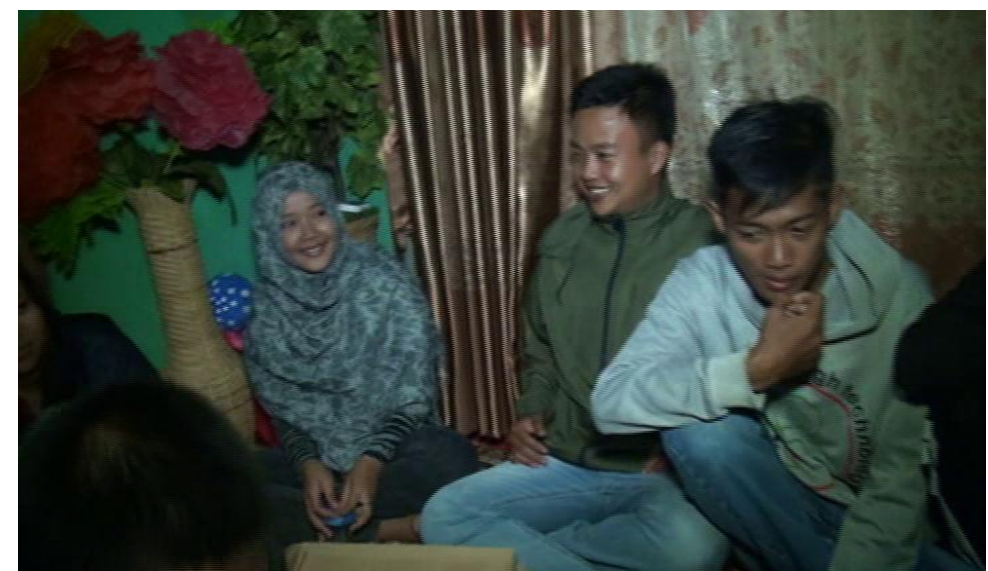

Foto 3 : Tradisi begareh di desaTalang Kelapa Kelurahan Tumbak Ulas, Pagar Alam ( Dokumentasi Dinas Pariwisata Kota Pagar Alam)

\section{Bentuk dan Struktur Pertunjukan Rejung}

\section{Bentuk Pertunjukan Rejung}

Rejung merupakan salah salah satu kesenian sastra tutur yang ada di Sumatera Selatan. Rejung biasanya disebut juga tembang batang hari sembilan dan juga biasa disebut gitar tunggal. Akan tetapi dari penyebutan tersebut terdapat perbedaan makna. Tembang batang hari sembilan adalah sebutan untuk kesenian sastra tutur yang diiringi oleh gitar yang ada di Sumatera Selatan secara umum atau keseluruhan tanpa membawa daerah atau suku. Sedangkan, gitar tunggal adalah sebutan untuk kesenian sastra tutur yang berisikan pantun yang dinyanyikan menggunakan iringan petikan gitar. Gitar tunggal adalah seni tradisi yang disajikan oleh seorang pemain gitar dan sekaligus sebagai penembang yang, Sedangkan Rejung adalah kesenian sastra tutur yang berisikan pantun yang dikemas dalam bentuk sebuah pertunjukan seni yang bisa dimainkan oleh satu atau dua orang. Berbeda dengan sebutan gitar tunggal dan tembang batang hari sembilan, sebutan untuk Rejung biasanya dipakai oleh masyarakat atau daerah tertentu yang ada di Sumatera Selatan seperti Pagar Alam (Arman, wawancara 12 Februari 2017 Tegur Wangi Pagar Alam).

Masyarakat Besemah memiliki dua sebutan untuk tradisi tembang batang hari sembilan yakni Rejung dan Berejung. Dalam hal ini keduanya memiliki perbedaan 
dalam bentuk penyajian dan kegunaan. Menurut Arman Idris Rejung adalah sebuah pantun yang diiringi oleh gitar yang dikemas dalam bentuk seni dan digunakan untuk media hiburan, Sedangkan Berejung adalah sebuah tradisi masyarakat Besemah mengungkapkan isi hati yang biasanya berisikan ratapan, kesedihan, dan kegelisahan yang ditembangkan di sawah atau kebun sebagai media memuaskan hati dan menjadi konsumsi pribadi.

Rejung merupakan media hiburan masyarakat Besemah, yang digunakan guna mengungkapkan ekspresi dan komunikasi. Berbicara tentang komunikasi, Rejung memiliki ruang sendiri pada adat perkawinan pada suku Besemah. Rejung pada adat perkawinan besemah dimainkan pada acara malam bujang gadis.

Pengertian bentuk yang dimaksud dalam bentuk penyajian kesenian Rejung pada acara begareh pada Malam bujang gadis di Kota Pagar Alam salah satunya adalah seperti yang diungkapkan Djelantik (1999:14) bahwa bentuk merupakan unsurunsur dasar dari susunan pertunjukan. Unsur-unsur penunjang yang membantu bentuk itu dalam mencapai perwujudannya yang khas adalah: a) seniman, b) alat musik, c) lagu yang disajikan d) kostum dan rias, e) Waktu dan tempat pertunjukan, f) penonton.

\section{a. Seniman}

Adapun unsur unsur dari bentuk penyajian pertunjukan salah satunya adalah seniman. Seniman yang ada pada pertunjukan Rejung tersebut biasanya terdiri dari satu atau dua orang seniman sebagai penembang dan pemetik gitar. Seperti penyebutanya Rejung biasanya dimainkan oleh satu orang yang merangkap dari penembang dan pemetik gitar. tetapi tidak menutup kemungkinan terjadi interaksi spontan antara penembang dan penonton.

\section{b. Alat Musik}

Selanjutnya adalah alat musik sebagai salah satu dari beberapa unsur pembentuk penyajian pertunjukan Rejung. Pertunjukan Rejung yang kita ketahui dengan nama lain adalah gitar tunggal. Seperti yang disebutkan Arman Idris Rejung adalah pantun yang dikemas dalam bentuk seni yang diiringi dengan alat musik. Alat musik yang populer untuk mengiringi Rejung pada zaman dahulu menurut Arman Idris adalah gitar. Ada beberapa alat musik yang pernah digunakan mengiri Rejung seperti rebab,dan harmonika.

Untuk penyeteman nada pada senar gitar yang digunakan untuk Rejung dilakukan sesuai kebutuhan dan lagu yang dimainkan. Berbeda dengan pantunya, lagu yang dimainkan dalam petikan disebut dawi, dawi tersebut terdiri dari beberapa macam seperti, dawi rai-rai, dawi naseb, dawi ribu, dan lain-lain. Dawi atau petikan tersebut merupakan petikan lagu populer yang ada, akan tetapi dari petikan tersebut boleh digunakan untuk pantun yang berbeda-beda. Seperti contoh lagu linjang sebelah menggunakan dawi rai-rai dengan urutan nada pada gitar sebagai berikut; senar keenam yang pada seteman umumnya bernada $E$ berubah menjadi nada $\mathrm{F}$, senar kelima dengan nada dasarnya A berubah menjadi G\#, senar keempat 
dengan nada dasar $\mathrm{D}$ berubah menjadi $\mathrm{C}$, kemudian pada senar ketiga dengan nada dasar $\mathrm{G}$ berubah menjadi $\mathrm{F}$, senar kedua yang bernada $\mathrm{B}$ berubah menjadi $\mathrm{A}$ dan senar pertama dengan nada dasar E berubah menjadi D\#.

\section{c. Lagu}

Lagu yang disajikan pada kesenian Rejung tergantung pada tempat dan dimana di tampilkan. Lagu-lagu yang berisikan pantun-pantun tersebut bisa hadir secara spontan dari seniman Rejung itu sendiri, Akan tetapi, dalam masyarakat Besemah terdapat lagu atau tembang yang populer salah satunya adalah lagu Linjang Sebelah. Berikut adalah lirik lagu Linjang Sebelah:

Lalame jagung ku ngendam. Jagung di ngendam lah dindak putih Jagung dingendam, jagung di ngendam lah dindak putih (Sudah lama jagung ku rendam. Jagung direndam tidak mau putih Jagung direndam, jagung direndam tidak mau putih)

La lame agungku dendam agung di dendam oi lah dindak nuleh Agung di dendam agung didendam oi dindak nuleh (Sudah lama agungku perhatikan agung di perhatikan oi tidak mau menoleh agung di perhatikan agung di perhatikan oi tidak menoleh)

Lemak nian dengah ka Lampung di tengah jalan pegi bedua Ditengah jalan pegi bedue. Lemak die dengah betunak Beghulas iluk bebande pule. Begulas ilok oi bebande pule.

(Bahagia sekali anda ke lampung di tengah jalan pergi berdua Ditengah jalan pergi berdua. Bahagia memang anda berkeluarga Berwajah cantik dan juga kaya. Berwajah cantik dan juga kaya)

Amu kami umpame padi sudeh di ketam deng lah ampe gale Sudeh di ketam oi lah ampe gale.

(Kalau saya umpamanya padi. Selesai dipanen dik tinggal sisa semuanya Selesai di panen oi tinggal sisa semuanya)

Amu kami udeh lah ini bebande dide oi bebande dide.

Be ulas kahgok bebande dide oi bebande dide.

Be ulas ilok bebande pule. Bukan kan endek ambikan jeme lok kami.

(Kalau saya sudah lah ini Kaya pun tidak oi kaya pun tidak

Berwajah jelek kaya pun tidak oi kaya pun tidak

Berwajah cantik dan juga kaya. Bukan untuk pilihan orang seperti kami)

Mance ku pisang bedahan dek tau kannye pisang be pelpah. Manceku linjang melawan dik taukanye badan linjang sebelah Oi nasib nasib, Dek taukanye badan linjang sebelah.

(Kusangka pisang berdahan dan kenyataanya pisang berpelepah Kusangka cinta di balas ternyata saya cinta sebalah 
Nasib oi nasib, ternyata saya cinta sebalah)

d) Kostum dan Tata rias

Kostum merupakan salah satu unsur dari bentuk penyajian dalam sebuah pertunjukan Rejung. Dalam hal ini biasanya seniman Rejung menggunakan pakaian adat dan terkadang hanya dengan tampilan sopan seperti menggunakan jas dan sepatu kulit. Akan tetapi yang tidak pernah tertinggal kostum dari seniman biasanya menggunakan tanjak dan kain sarung untuk menunjukan kesan tradisi dan karakter dari daerahnya.

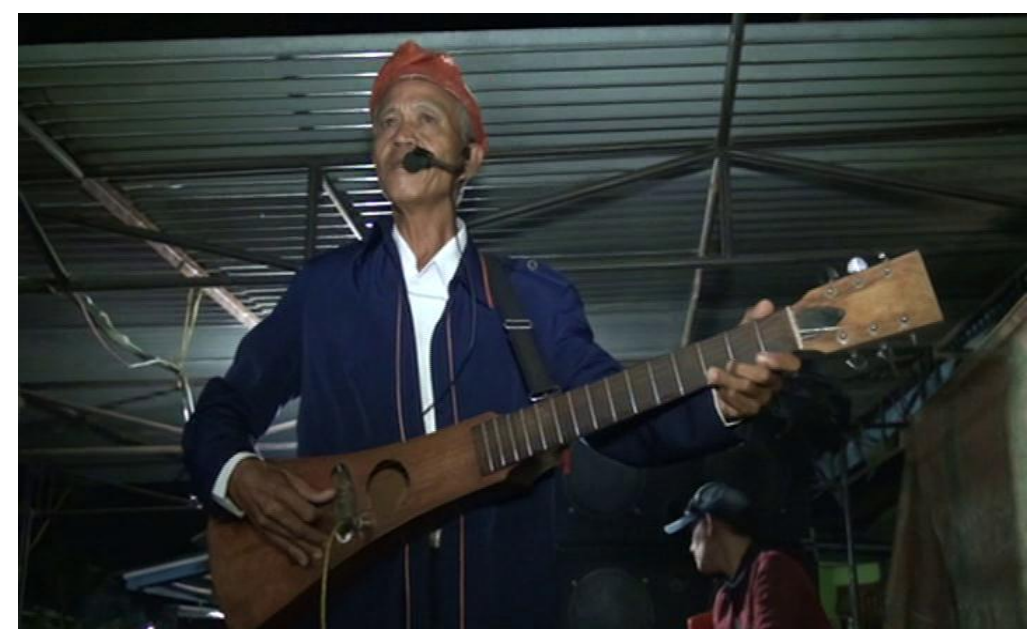

Foto 1. Penembang rejung dengan alat musik Gitar dan kostum

e) Waktu dan Tempat Pertunjukan

Tempat pertunjukan kesenian Rejung dilakukan diatas panggung yang disediakan biasanya pada acara perkawinan panggung tempat pelaminan digunakan untuk tempat seniman melangsungkan pertunjukan. Tidak menutup kemungkinan pertunjukan juga terjadi didalam ruangan biasanya pertunjukan yang terjadi didalam ruangan pada acara malam bujang gadis atau tradisi begareh. Waktu terjadinya kesenian Rejung biasanya pada malam hari sebelum hari resepsi perkawinan dan siang hari pada acara hiburan pada resepsi perkawinan.

\section{f) Penonton}

Penonton atau penikmat kesenian Rejung biasanya bersifat acak tidak adak kekhususan untuk penonton pada kesenian ini. Tetapi Rejung biasanya dinikmati oleh orang-orang yang sudah berumur (tua). Berbeda dengan lokasinya, lokasi menentukan penonton. Penulis menemukan penikmat kesenian Rejung di daerah atau dusun lebih banyak dari pada penikmat di daerah kota. Hal tersebut berpengaruh dengan kemampuan masyarakat kota menterjemahkan Rejung. Bahasa di dusun tidak bercapur seperti di kota. Masyarakat Pagaralam yang ratarata memiliki dua bahasa yaitu bahasa Besemah dan bahasa Palembang. Hal 
tersebut membuat banyak dari masyarakat kota tidak mengerti dengan bahasabahasa yang ada pada pantun yang berisi bahasa yang asli suku Besemah.

Bebeda dengan bentuk pertunjukan Rejung muda-mudi, pertunjukan yang dilakukan pada tradisi begareh pada malam bujang gadis yang dilakukan di dalam ruangan. Muda-mudi yang hadir dalam tradisi ini bisa menjadi penonton dan penembang, karena dalam pertunjukan Rejung muda-mudi siapapun yang hadir boleh merayu dengan menggunakan tembang. Hal tersebut yang membuat penulis menyimpulkan bahwa penonton pada tradisi Rejung muda-mudi bisa menjadi penonton dan penembang dalam hal ini disebut sebagai pelaku.

\section{Struktur pertunjukan Rejung}

Struktur dasar pertunjukan (deep structures) oleh Schechner dibagi menjadi tiga tahap, yaitu (1) persiapan, (2) pertunjukan, (3) aftermath. Tahap persiapan mencakup antara pemain dan penonton. Pemain menyiapkan latihan, workshop, dan persiapan pentas, sedangkan penonton meyiapkam diri dalam hal memilih pertunjukan, memakai pakaian yang pantas, menunggu pertunjukan dimulai. Tahap pertunjukan atau pementasan adalah pristiwa saaat pemain melakukan pertunjukan. Adapun aftermath adalah serangkaian kegiatan yang dilakukan setelah pertunjukan selesai. Misalnya, membongkar set, mengembalikan peralatan atau barang-barang ke tempatnya, dan beristirahat. Selanjutnya mengevaluasi, menulis resensi pertunjukan, dan mngumpulkan tanggapan penonton. (Schechner dalam Asril, 2016:155).

Pertunjukan Rejung ditampilkan menurut tahap-tahapnya hingga menjadi struktur pertunjukan. Untuk melihat struktur pertunjukan Rejung harus dimulai dengan melihat tahapan- tahapan tersebut.

\section{a. Persiapan}

Persiapan yang dilakukan dalam sebuah pertunjukan Rejung secara umum adalah latihan dan menyiapkan pantun yang akan ditembangkan. Akan tetapi, penullis harus membagi bentuk pertunjukan Rejung terlebih dahulu untuk menjelaskan tahapan persiapan tersebut. Pertama adalah rejungan dalam hal ini Rejungan adalah pertunjukan Rejung yang menggunakan jasa seniman penembang untuk menghibur pada pesta perkawinan khusunya pada tradisi begareh pada Malam bujang gadis sebagai bentuk hiburan. Kedua yaitu Rejung muda-mudi merupakan pertunjukan Rejung yang dilakukan oleh muda-mudi sebagai bentuk hiburan pada Malam bujang gadis pada tradisi begareh.

Persiapan yang dilakukan oleh seniman Rejung biasanya adalah menyiapkan pantun, kostum, dan alat musik. Menyiapkan pantun beguna untuk membantu penembang, karena tembang atau pantun yang akan dinyanyikan bersifat berubahubah tergantung dari keadaan, tempat dan acara yang dilakukan. Karena Rejung bersifat hiburan memiliki kebebasan untuk ditampilkan dimanapun dengan kondisi apapun. Dalam persiapan pertunjukan Rejung tidak ada persiapan perilaku yang bersifat ritual, tetapi penembang Rejung harus lebih selektif dalam memilih 
kata-kata dalam pantun, guna menjaga bentuk komunikasi masyarakat Besemah yang terkenal dengan bahasa yang lebih sopan. Persiapan selanjutnya adalah menyiapkan kostum, untuk kostum yang digunakan seniman Rejung biasanya kostum yang sederhana seperti kemeja putih, jas, kain, tanjak, dan sepatu kulit. Dalam pertunjukan Rejungan ini tidak ada kostum khusus yang mewakili bentuk pertunjukan.

Tahapan persiapan Rejung muda-mudi biasanya para muda-mudi telah menyiapkan pantun yang akan ditembangkan, akan tetapi karna Rejung mudamudi ditampilkan atau dimainkan pada tradisi begareh pada malam bujang gadis, pantun yang disiapkan sudah memiliki sasaran kepada siapa akan ditujukan. Seperti yang diungkapkan Malkat, tradisi begareh pada malam bujang gadis sering digunakan untuk mencari jodoh atau pasangan, tidak jarang para pemuda yang akan mengikuti tradisi begareh sudah menentukan untuk siapa pantun tersebut akan ditembangkan. Akan tetapi tidak jarang pantun yang telah dipersiapkan tersebut berubah kepada orang lain, karena pada tradisi begareh pada malam bujang gadis tersebut, muda-mudi yang datang bisa dari mana saja dan siapapun boleh menghadiri tradisi tersebut (Wawancara, Malkat 8 April 2017, Palembang)

\section{b. Pertunjukan}

Pertunjukan Rejung dilakukan dalam bentuk pertunjukan sering terjadi pada tradisi malam bujang gadis. Rejung sendiri yang pada awalnya merupakan bentuk hiburan, dan hanya dinikmati untuk kepentingan pribadi untuk mengungkapkan perasaan yang ada dalam diri. Dalam pertunjukan Rejung pada Malam bujang gadis terbagi menjadi dua cara yaitu pertunjukan hiburan Rejung muda-mudi, dan Rejungan. Pertunjukan Rejung muda-mudi adalah bentuk pertunjukan spontan yang dilakuan oleh muda-mudi pada tahun 1980an. Hal tersebut terjadi karena pada masa itu, para muda-mudi bisa memainkan Rejung secara personal. Penonton Rejung muda-mudi biasanya hanya untuk muda-mudi yang hadir di tradisi begareh pada malam bujang gadis. Rejung muda-mudi yang bersifat spontan menjadikan tempat pertunjukan hanya sebuah ruangan yang digunakan pada tradisi begareh tersebut.

Malkat mengungkapkan biasanya setelah Rejung muda-mudi berlangsung, penembang akan langsung mendapat respon dari sasaran pantun, biasanya terjadi interaksi yang lebih mendalam. Seperti yang dikatakan Malkat ada istilah ndamping dalam tradisi begareh setelah pentunjukan Rejung muda-mudi. Istilah ndamping yang berarti mendekat, dalam hal ini berarti mendapat kesempatan untuk lebih mengenal dekat seseorang dengan cara berbincang berdua. Hal tersebut dapat terjadi selama tradisi begareh berlangsung, biasanya hal tersebut dicirikan dengan duduk yang berdekatan dan interaksi yang dilakukan dominan hanya antara mereka berdua.

Sedangkan Rejungan adalah bentuk hiburan Rejung yang dimainkan oleh seniman Rejung. Istilah untuk Rejungan itu sendiri baru muncul sekitar tahun 1990an 
seiring dengan banyaknya masyarakat yang tidak bisa lagi berpantun pada masa kini. Seiring dengan berkurangnya kemampuan masyarakat yang dapat memainkan Rejung sencara personal, maka kesenian tersebut berubah menjadi bentuk sebuah pertunjukan dalam sebuah acara-acara pada masyarakat salah satunya di tradisi begareh pada Malam bujang gadis.

Dalam tulisan ini penulis membahas bagaimana bentuk pertunjukan Rejungan tersebut. Penulis menjelaskan bagaimana stuktur pertunjukan Rejung di tradisi begareh pada malam bujang gadis. Pertunjukan Rejungan dilakukan di atas panggung, penembang biasanya menggunakan pakaian yang sopan seperti jas yang dilengkapi dengan tanjak dan kain sebagai karakter yang mewakili daerahnya. Alat musik yang digunakan adalah gitar akustik yang menggunkan senar dari kawat. Pada pertunjukan Rejungan terdapat tradisi sumbangan, yang dimaksud dengan sumbangan adalah seniman Rejung akan menyiapkan kotak kardus kosong yang akan di letakan di depan panggung untuk diisi oleh penonton sebagai bentuk sumbangan untuk seniman.

\section{c. Aftermath}

Tahapan selanjutnya adalah aftermath yaitu tahapan terakhir dalam sebuah sturktur pertunjukan. Tahapan ini merupakan tahapan akhir setelah pertunjukan selesai. Pada pertunjukan Rejungan tahap ini digunakan oleh penembang untuk mengumpulkan uang saweran dari penonton setelah pertunjukan selesai penembang akan menutup kotak kardus yang telah disediakan dan mengumpulkan uang saweran kemudian mengumumkan jumlah uang yang didapat. Kemudian mengucapkan rasa terimakasih kepada penonton yang telah menyumbang. Setelah itu penembang akan merapikan alat-alat yang telah digunakan dalam pertunjukan, dan yang terakhir penembang akan mendapat jamuan dari tuan rumah sebagai bentuk ucapan terima kasih dari tuan rumah.

Seperti yang dijelaskan pada tahapan pertunjukan Rejung muda-mudi diatas, bahwa dalam tradisi tersebut terjadi interaksi antara muda-mudi, seperti ndamping. Hal tersebut terjadi biasanya selama proses begareh berlangsung. Selanjutanya apabila interaksi tersebut berhasil akan terjadi istilah ngantat balek. Dalam bahasa besemah ngantat yang berarti menghantarkan dan balek adalah pulang(tujuan rumah). Apabilah hal tersebut terjadi maka seorang laki-laki dapat dikatakan berhasil merebut hati seorang perempuan, karena pada adat masyarakat Besemah istilah ngantat balek bisa berarti siap menanggung dan bertanggung jawab atas apa yang terjadi pada seorang perempuan dan juga menjadi sebuah kerhormatan bagi seorang laki-laki pada masyarakat Besemah. Dituturkan oleh Malkat apabila telah terjadi hal tersebut dapat dikatakan berhasil dalam tradisi begareh tersebut (Wawancara, Malkat 8 April 2017, Palembang) . 


\section{KESIMPULAN}

Kesenian tradisonal sastra tutur yang tersebar ada di Sumatera Selatan yaitu salah satunya adalah Rejung. Merupakan kesenian tradisional yang menggunakan pantun serta kombinasi dengan petikan gitar yang di satukan menjadi sebuah kesatuan. Sedangkan malam bujang gadis adalah salah satu dari susunan adat perkawinan yang ada pada suku besemah. malam bujang gadis yang berisikan acara begareh yang pada hakikatnya adalah kegiatan bagi para muda-mudi untuk membantu dalam menghias ruangan untuk memperindah dekorasi pada perkawinan suku besemah. Tradisi ini juga digunakan sebagai media komunikasi bagi para muda-mudi dalam mencari pasangan.

Bentuk pertunjukan pada Rejung dalam begareh Malam bujang gadis memiliki beberapa unsur seperti seniman, alat musik, busana dan tata rias, lagu, lokasi pertunjukan, waktu dan penonton. Seniman pada rejung disebut sebagai penembang dengan menggunakan alat musik gitar. Kostum yang digunakan adalah jas tanjak dan kain sarung, kemudian lagu yang dibawakan bersifat random pantun-pantun bisa tercipta dari kondisi yang ada pada saat pertunjukan, tetapi masyarakat besemah juga memiliki beberapa lagu populer yang ada, salah satunya adalah lagu Linjang Sebelah.

Maka dari itu, unsur-unsur yang ada dalam pertunjukan rejung dalam begareh tersebut sangatlah penting untuk membentuk sebuah pertunjukan rejung pada Malam bujang gadis. 


\section{DAFTAR RUJUKAN}

A.A.M. Djelantik (1999), Estetika: Sebuah Pengantar, Bandung: Masyarakat Seni Pertunjukan Indonesia.

Asril. (2016), Tabuik: Pertunjukan Budaya Hibrid Masyarakat Kota Pariaman, Sumatera Barat (Desertasi), Yogyakarta: Institud Seni Indonesia Yogyakarta.

Firmansyah Feri. (2014). Sahilin Dalam Dunia Musik Batanghari Sembilan Di Palembang (Kesenimanan Dan Gaya Musiknya) (Tesis), Surakarta: institut seni indonesia Surakarta.

Firamadhan, Arza Wahyu. (2015), Musik Rejung Dalam Sastra Lisan Etnis Besemah Kabupaten Pagaralam(Skripsi), Yogyakarta: Institut Seni Indonesia Yogyakarta.

Lembaga Adat Besemah.tt, Himpunan Adat Istiadat Besemah.

Misral dkk. (2014). Musik Etnik di Sumatera Selatan. Palembang: Dinas Pendidikan Sumatera Selatan.

\section{DAFTAR NARASUMBER}

Arman Idris (62), Seniman Sastra tutur Sumatera Selatan. Desa Tegur Wangi Kota Pagar Alam.

Malkat (35), masyarakat Besemah pelaku pada tradisi begareh. Desa Jambat Bale Kota Pagar Alam.

Satarudin Tjik Olah (90), Budayawan Besemah dan Ketua Lembaga Adat Besemah. Desa Mekar Alam Kota Pagar Alam. 